\title{
PACKAGING PRODUK SUSU KAMBING ETAWA "ETTAKOLET" DI DESA WISATA CIKOLELET SERANG
}

\author{
Chotibul Umam ${ }^{1}$, Rina Fitriana ${ }^{2}$ \\ ${ }^{1}$ Universitas Banten Jaya, Jl Syech Nawawi Albantani Serang, Banten, Indonesia \\ ${ }^{2}$ Sekolah Tinggi Pariwisata Trisakti, Jl. IKPN Bintaro Bintaro, Kec. Pesanggrahan, Kota Jakarta Selatan \\ E-mail: chumam.umam@gmail.com
}

\begin{abstract}
This article describes the training activities for packaging etawa goat milk produced by Cikolelet Tourism Village, Serang Regency, Banten. The village's potential and nature in Cikolelet Banten are very rich with agricultural and plantation products and livestock. One of the superior products of the tourist village is etawa goat milk. This goat milk already has a market among residents around tourist villages, unfortunately the packaging is still fairly simple and does not yet have a brand, therefore it is considered less attractive for tourists. The methods used in this community service are observation, interviews, discussions, practice of brand packaging and installation applications, as well as assistance and monitoring evaluation. The subjects of this training were farmers from five etawa goat farms in Cikolelet village. The results of this packaging training activity is the change in product packaging using boxshaped plastic bottles that have been branded to make it more attractive. Packaging and manufacturing of goat's milk product brands succeeded in increasing sales volume by $20 \%$ with prices increasing by $25 \%$ from the previous selling price. It is expected that this change can make etawa goat milk produced by Cikolelet Village will be better known by the public, as well as favored by tourists.
\end{abstract}

Keywords: Village Potential, Etawa Goat Milk, Packaging, Cikolelet Tourism Village.

\begin{abstract}
ABSTRAK
Artikel ini menjelaskan tentang kegiatan pelatihan pengemasan susu kambing etawa produksi Desa Wisata Cikolelet Kabupaten Serang Banten. Potensi desa dan alam di Cikolelet Banten sangatlah kaya dengan hasil pertanian dan perkebunan serta peternakan yang melimpah. Salah satu produk unggulan desa wisata tersebut adalah susu kambing etawa. Susu kambing ini sudah memiliki pasar di kalangan warga sekitar desa wisata, namun sayang pengemasannya masih terbilang sederhana dan belum memiliki merk sehingga kurang menarik untuk dijadikan buah tangan wisatawan. Metode yang digunakan dalam pengabdian masyarakat ini adalah observasi, interview, diskusi, praktek aplikasi pengemasan dan pemasangan merk, serta pendampingan dan monitoring evaluasi. Subjek dari pelatihan ini adalah para peternak dari lima peternakan kambing etawa di desa Cikolelet. Hasil dari kegiatan pengabdian pengemasan ini yaitu adanya perubahan pengemasan produk menggunakan botol plastik berbentuk kotak yang telah ditempeli merk sehingga lebih menarik tampilan produknya. Pengemasan dan pembuatan merk produk susu kambing ini berhasil meningkatkan volume penjualan sebesar $20 \%$ dengan harga yang meningkat sebesar sebesar $25 \%$ dari harga jual sebelumnya. Diharapkan dengan adanya perubahan ini dapat membuat susu kambing etawa produksi Desa Cikolelet lebih dikenal masyarakat dan disukai wisatawan.
\end{abstract}

Kata kunci : Potensi Desa, Susu kambing Etawa, Pengemasan, Desa Wisata Cikolelet

\section{PENDAHULUAN}

Pariwisata merupakan salah satu sektor yang masuk dalam prioritas pembangunan pemerintah. Hal ini disebabkan besarnya sumbangan pariwisata terhadap devisa, seperti yang 
dikemukakan oleh Menteri Pariwisata dan Industri Kreatif Arif Yahya, "Untuk Indonesia, pariwisata jadi penghasil terbesar devisa kedua... Pariwisata hanya kalah dari sektor kelapa sawit" (m.republika.co.id)

Hal lain yang menjadi kelebihan pariwisata adalah kemampuannya untuk mengatasi angka pengangguran yang semakin besar. Sebagian besar tenaga kerja yang dibutuhkan dan diserap bidang ini adalah mereka yang terampil dan bukan yang berpendidikan tinggi, yang mana hal ini sangat cocok bagi Indonesia yang memiliki jumlah penduduk dengan jumlah cukup besar dengan tingkat angkatan kerja yang tinggi.

Demi terserapnya angka tenaga kerja yang besar tersebut, dalam beberapa tahun ini telah terjadi pergeseran pembangunan pariwisata dimana sektor ini, ditiitkberatkan di daerah pedesaan. Pembangunan pariwisata berbasis masyarakat (Community Based Tourism) dianggap sebagai jalan untuk mendongkrak kesejahteraan suatu wilayah. Banyak wisata baru yang dikembangkan oleh masyarakat desa, dengan gerakan sadar wisata dan sapta pesona yang digalakkan pemerintah melalui Kementerian Pariwisata dan Ekonomi Kreatif sebagai tonggaknya.

Menurut Mulyadi (2009:7), definisi pariwisata adalah suatu aktivitas, pelayanan, dan produk hasil industri pariwisata yang mampu menciptakan pengalaman perjalanan bagi wisatawan. Menurut Sugiwa (2014: 105), analisis profil pariwisata Banten diuraikan sebagai berikut: (1) atraksi, dan (2) fasilitas. Adapun yang dimaksud dengan atraksi tidak hanya terbatas pada jenis kesenian saja, akan tetapi juga meliputi semua kegiatan yang ada di suatu destinasi yang dapat menarik dan menghibur wisatawan.

Dengan mengacu pada pengertian tersebut, salah satu daerah di provinsi Banten yang dianggap sebagai daerah dengan potensi wisata adalah desa Cikolelet Kecamatan Cinangka Kabupaten Serang Provinsi Banten, memiliki daya tarik tersendiri bagi wisatawan lokal maupun mancanegara. Secara geografis, desa ini terletak di dataran tinggi dan dikelilingi oleh persawahan dan perbukitan sehingga memiliki udara yang sejuk dan sangat cocok untuk kegiatan bercocok tanam dan peternakan. Desa Cikolelet yang terdapat di Kecamatan Cinangka Kabupaten Serang Banten pada awalnya dianggap sebagai desa yang kurang berkembang, namun sejak dilakukannya pemanfaatan beberapa objek wisata di daerah tersebut, kesejahteraan penduduk pun dapat ditingkatkan menjadi lebih baik

Selain daya tarik alam, atraksi lainnya adalah peternakan kambing etawa di desa Cikolelet yang menghasilkan susu kambing etawa, hal ini dapat dikategorikan sebagai sebuah atraksi. Di peternakan ini, para pengunjung ikut serta memberi makan kambing etawa, menonton proses pemerahan susu kambing hingga membeli produk susu yang masih segar. 
Masyarakat disini memiliki ratusan kambing etawa yang produktif yang dapat menghasilkan susu setiap harinya, dengan jumlah produk ebanyak itu, maka implikasi terhadap tenaga kerja yang diserap juga relatif banyak, mulai pekerja yang mengurus kandang sampai kepada pedagang susu etawa eceran yang membeli dari produsen susu etawa ini untuk dijual kembali kepada warga di kampung-kampung sekitar maupun pada pengunjung yang datang di banyak objek wisata yang ada di kecamatan Anyer dan Cinangka.

Menurut hasil penelitian United State Departement of Agriculture (USDA) susu kambing etawa mengandung 3-4\% protein, 4-7 \% lemak, 4,5\%karbohidratm 134 gram kalsium dan $111 \mathrm{~g}$ fosfor. Dari segi kesehatan, kandungan susu kambing etawa terdapat berbagai manfaat dan memiliki beberapa kelebihan dibandingkan dengan susu sapi. Diantara kebaikan susu ini bagi kesehatan tubuh yaitu: membantu pencernaan, penyembuhan asma, menambah stamina dan daya tahan tubuh dan sebagianya.

Namun permasalahan yang ada, produk susu kambing etawa masih memiliki kemasan yang sederhana dan kurang menarik. Padahal bagi pengunjung a kemasan dipadanng penting karena fungsinya yang merapikan dan melindungi produk dari pengaruh sekitarnya yang akan merusak terhadap kualitas produk tersebut (Widyatmoko dalam Mukhtar et al, 2015:182). Mengacu pada analisis situasi di atas, permasalahan mitra adalah:

a. Belum adanya pemahaman produsen susu kambing etawa tentang fungsi kemasan dan merk bagi penjualan produk.

b. Pengemasan produk susu kambing etawa di desa Cikolelet masih sangat sederhana yaitu menggunakan plastik biasa.

c. Kemasan susu kambing etawa di Desa Cikolelet belum menggunakan merk.

\section{METODE}

Metode pelaksanaan pada kegiatan pengabdian masyarakat ini dengan menggunakan beberapa cara yaitu observasi, interview, diskusi, praktek aplikasi pengemasan dan pemasangan merk, serta monitoring evaluasi.

a. Observasi yaitu mengamati bagaimana penjualan produk yang masih dikemas dengan sederhana dan belum memiliki merk.

b. Interview yaitu menanyakan pada produsen apa yang sebetulnya diharapkan dari produk namun belum bisa dicapai sampai sekarang.

c. Diskusi dengan produsen tentang bagaimana kemasan yang kira-kira cocok mewakili produk mereka karena setiap produk memiliki karakteristik tertentu.

d. Praktek aplikasi pengemasan, yaitu saat hasil dari pemilihan kemasan dan merk dagangnya mulai dipakai dalam produk yang akan diperdagangkan. 
e. Monitoring evaluasi dengan cara memantau bagaimana produk setelah diberi kemasan, baik dari segi volume penjualan maupun harganya. Serta menampung masukan dari konsumen tentang kemasan dan merk tersebut sehingga bisa dilakukan perbaikan apabila dirasa ada yang kurang cocok atau tidak mewakili produk yang dijual. Pemilik/produsen susu kambing etawa dan pemerintahan Desa Cikolelet serba membuat surat kerjasama mitra. Pihak pemerintah Desa juga memberikan undangan resmi untuk memberi pelatihan

\section{HASIL DAN PEMBAHASAN}

Untuk mencapai target yang diharapkan, maka dilakukan beberapa tahapan dalam program pengabdian kepada masyarakat yang dilakukan pada bulan Februari 2018 ini, yaitu:

1. Persiapan

Tim pengabdian masyarakat mengurus perizinan kepada para pemilik/produsen susu kambing etawa dan pemerintahan Desa Cikolelet serba membuat surat kerjasama mitra. Selain itu juga mempersiapkan data yang terkait dengan produksi susu kambing etawa, diantaranya mengenai volume penjualan, harga jual produk, pasar produk susu etawa, dan sebagainya. Pihak pemerintah Desa juga memberikan undangan resmi untuk memberi pelatihan

2. Pelatihan

Tim pengabdian masyarakat datang ke lokasi pelatihan yang dipusatkan di Balai Desa Wisata Cikolelet dan memberikan beberapa materi terkait produksi dan pemasaran susu, diantaranya tentang bagaimana pentingnya hygiene dan sanitasi produk, tentang efek packaging dan merk bagi penjualan produk susu etawa, serta bagimana menghitung harga jual dan berapa rasio keuntungan yang normal.

3. Praktik Pengemasan

Melakukan kegiatan pengemasan yang diawali dengan diskusi untuk secara bersama memilih kemasan (packaging) yang dianggap paling tepat, baik dari segi harga kemasan, bentuk maupun kemampuannya dalam melindungi produk. Dalam tahap ini dipilihlah botol berbentuk segi empat karena dari segi harga dipandang paling ekonomis, dan paling aman dari segi bentuk karena memiliki bentuk yang bergelombang yang akan memudahkan pegangan konsumen saat meminum dan mencegah produk mudah terlepas dari genggaman.

Hal lain yang dilakukan dalam tahapan ini adalah memutuskan merk yang akan digunakan, termasuk dalam desain dan pencetakan merknya. Diputuskan bahwa kemasan merk akan dibuat gambar yang menunjukkan keaslian dan kesegaran susu etawa. Adapun merk dagangnya diputuskan "Ettakolet" yang merupakan singkstan dari Etawa Cikolelet. 
Dalam tahapan ini pula produsen bersama dengan tim menghitung penyeusaian harga jual yang wajar yang disebabkan oleh biaya yang ditimbulkan dengan adanya packaging dan merk. Dan diputuskan bahwa kenaikan harga yang wajar karena kemasan yang dibuat lebih menarik adalah sebesar $25 \%$ dari harga jual semula.

4. Monitoring dan Evaluasi

Melakukan evaluasi bersama mitra pengabdian masyarakat dan tim pengabdian. Memberi kesempatan tanya jawab dan membantu mitra pengabdian menjawab permasalahan yang mereka hadapi terkait dengan digunakannya kemasan dan merk dagang yang baru. Pasca pengemasan produk dengan membandingkan volume penjualan yang menggunakan kemasan sederhana, setelah melakukan penjualan produk selama seminggu diketahui bahwa volume penjualan dari 550 botol per minggu meningkat sebanyak 20\% menjadi 660 perminggu dengan harga dari 10 ribu menjadi 12.500 perbotolnya, penjualan ini dilakukan melalui metode yang biasa, yaitu dengan menjual langsung di peternakan juga penjualan yang dilakukan dengan cara khusus seperti pameran.

Tim pengabdian melakukan evaluasi produk agar ke depan volume dan harga produk dapat lebih ditingkatkan lagi. Selain itu tim juga melihat kekurangan yang msih ada dalam produk sehingga bisa menjadi bahan evaluasi dan dijadikan sasaran bagi pengabdian masyarakat yang selanjutnya.

\section{KESIMPULAN}

Kesimpulan dari pengabdian masyarakat ini yaitu pelatihan tentang arti penting kemasan produk dalam penjualan dan pengemasan serta pemerkan itu sendiri sangatlah dibutuhkan. Hal ini tebukti dari terdapatnya peningkatan harga jual dan volume penjualan produk setelah dikemas dan diberi merk.

\section{DAFTAR PUSTAKA}

Muljadi, Aj. (2009). Kepariwisataan dan Perjalanan. Jakarta: STMT Trisakti.

Sugiwa, Iwan. (2014). Profil Obyek Dan Tujuan Wisata (ODTW) di Provinsi Banten Dan Daya Tariknya Terhadap Wisatawan. Jurnal Epigram, Vol. 10 No.2. 102-109.

Mukhtar, Syukrianti dan Nurif, Muchammad (2015) Peranan Packaging dalam Meningkatkan Hasil Produksi terhadap Konsumen. Jurnal Sosial Humaniora, Vol 8 No. 8. 121-191 Https://republika.co.id/berita/kolom/wacana/18/10/12/pggopd440-meraup-devisa-pariwisata menguatkan-ekonomi. Diunggah pada 5 Januari, 2019. Pukul 19.45 WIB 